\title{
Plankton community structure and carbon cycling on the western coast of Greenland during the stratified summer situation. III. Mesozooplankton
}

\author{
Benni Winding Hansen ${ }^{1, *}$, Torkel Gissel Nielsen², Henrik Levinsen ${ }^{2}$ \\ ${ }^{1}$ Roskilde University, Department of Life Sciences and Chemistry, PO Box 260, DK-4000 Roskilde, Denmark \\ ${ }^{2}$ National Environmental Research Institute, Department of Marine Ecology and Microbiology, Frederiksborgvej 399, \\ PO Box 358, DK-4000 Roskilde, Denmark
}

\begin{abstract}
The mesozooplankton community in Disko Bay, West Greenland, was examined by stratified sampling with a WP-2 net $(200 \mu \mathrm{m})$, as well as a Hensen $(45 \mu \mathrm{m})$ net, during the period of stratification in late summer 1994. Copepod biomass in the upper $50 \mathrm{~m}$ declined over the interval from $20 \mathrm{mg}$ $\mathrm{C} \mathrm{m}^{-3}$ to virtually nothing due to the downward seasonal migration by Calanus spp. The ontogenetic vertical distribution of larger species, Calanus spp., revealed that the juvenile stages predominantly were associated with upper water strata and remained there until September. The decline in Calanus dominance was followed by increasing abundance of smaller copepods (Pseudocalanus, Oithona and Acartia) and of meroplanktonic larvae, a general restructuring of the grazer food chain in the euphotic zone. The large Calanus spp. had finished their spawning season before late August, while small copepods produced eggs throughout late August to mid-September. According to a statistical path analysis the specific egg production of Acartia longiremis was associated primarily with phytoplankton biomass and secondarily with protozooplankton biomass. Daily egg production per female declined gradually from $10 \mathrm{~d}^{-1}$ on August 27 to $1.6 \mathrm{~d}^{-1}$ on September 27. The biomass of A. longiremis was rather modest, indicating that it was not a dominant grazer in the euphotic zone. Weight specific egg production of $A$. longiremis declined from 0.11 to $0.02 \mathrm{~d}^{-1}$, and was used as an index for secondary production; grazing by mesozooplankton was subsequently estimated as $3 \times$ secondary production. Grazing impact was thereby roughly calculated for the entire copepod standing stock and compared with data from parallel studies on phytoplankton, bacteria and protozooplankton into a comprehensive pelagic carbon budget for the euphotic zone, the upper $30 \mathrm{~m}$. The estimated total grazing upon phytoplankton was 3 times the primary production. It is proposed that phytoplankton was primarily grazed by ciliates and secondarily by ciliated meroplankton and copepods. Additionally, a large fraction of the ciliate production was presumably grazed by heterotrophic dinoflagellates. The protozooplankton were key grazers in the pelagic carbon cycling of Disko Bay.
\end{abstract}

KEY WORDS: Arctic mesozooplankton - Egg production - Life strategies - Carbon budget

\section{INTRODUCTION}

Copepods of the genus Calanus dominate the mesozooplankton biomass in Arctic ecosystems and their life cycles influence pelagic carbon flow and the recruitment and survival of fish in Arctic waters (e.g. Hassel et al. 1991, Runge \& Lafontaine 1996). The reproductive cycle of these large copepods involves

-E-mail: bhansen@ruc.dk vertical migration from their deep water hibernation refuge to the upper water strata in the spring (Marshall \& Orr 1955, Tande 1982, Båmstedt \& Tande 1988, Pedersen et al. 1995). During early summer the egg production by $C$. finmarchicus and $C$. glacialis peaks (Nielsen \& Hansen 1995). After spawning, the Calanus spp. population build up lipid reserves whereafter vertical migration to deep water for hibernation is initiated (Miller et al. 1991).

Egg production rate of Calanus finmarchicus and $C$. glacialis off West Greenland follows the peak of 
chlorophyll concentration (Nielsen \& Hansen 1995), as recorded from other areas (Hirche \& Bohrer 1987, Melle \& Skjoldal 1989, Peterson et al. 1991, Diel \& Tande 1992, Plourde \& Runge 1994, Hirche \& Kwasniewski 1997). Additionally, it has been suggested that egg production by $C$. finmarchicus can derive from other food sources, mainly microzooplankton, during midsummer (Kleppel et al. 1988, 1991, Ohman \& Runge 1994, Barthel 1995, Runge \& Lafontaine 1996). However, other species may not depend so directly upon immediate nutrition. Smith (1990) reported egg production by C. glacialis before the spring bloom and C. hyperboreus has actively reproduced well in advance of the spring bloom based solely on stored energy (Conover 1965, Hirche \& Niehoff 1996).

During summer the juvenile Calanus spp. dominate the mesozooplankton community in the upper water strata, whereas the more advanced copepodite stages are to be found in deeper water strata (Unstad \& Tande 1991, Pedersen et al. 1995, Falkenhaug et al. 1997a). This distribution was proposed to be due to ontogenetic migration (Unstad \& Tande 1991). When the bulk of the copepod biomass migrates out of the photic zone the grazing potential by the copepod community must be substantially reduced.

Knowledge of the significance of smaller species, i.e. Pseudocalanus spp., Acartia spp. and Oithona spp., in the Arctic is limited due to undersampling by coarse plankton nets. However, the appearance of these small species following the large species in the yearly succession is well documented (e.g. Jespersen 1934, Smidt 1979). Populations of small copepods increase in the upper water masses during late summer and autumn in the Barents Sea and a North Norwegian fjord (Tande 1991. Barthel 1995). In contrast to large copepods, the smaller copepods likely go through several (2 or 3 ) generations per year (Norrbin 1991, 1992, Falkenhaug et al. $1997 \mathrm{~b}$ ), but their role in pelagic carbon flow is unassessed.

Information concerning grazing and growth by the most important small copepods is rather limited from cold water areas. Hansen et al. (1994a) documented grazing on diatoms 30 to $40 \mu \mathrm{m}$ in diameter, but not upon Phaeocystis colonies or single cells, by Acartia longiremis. Runge \& Ingram $(1988,1991)$ reported substantial under-ice grazing by Pseudocalanus spp. in Hudson Bay before and after the spring bloom. The only secondary production study we know of is by Hasset et al. (1993), who reported egg production by Acartia tumida related to food concentration and quality during summer in the Aleutian Archipelago. Generally, there is a serious lack of knowledge about the biology of small copepods in Greenland waters and no previous investigations have described the quantitative species composition and compared secondary pro- duction of small versus large copepods during the transition from summer to autumn.

Most of the benthic invertebrates include a larval stage in their life cycle. Planktotrophic larvae require several weeks in the plankton to develop competence for metamorphosis and settling. The timing of the pelagic phase, the abundance as well as the trophic significance of these microphagous particle grazers are, however, unknown.

In the present study life strategies and succession of the various mesozooplankton groups are evaluated along with the change in plankton structure from midJuly to mid-September. Changes in the pelagic carbon cycle associated with the disappearance of the bulk of the copepod community from the euphotic zone are also discussed. Relaxation of grazing by large copepods is hypothesized to affect carbon cycling, since small copepods, meroplankton and protozooplankton retain smaller food particles more efficiently than larger copepods, thereby influencing the plankton community structure by grazing upon the smallest heterotrophic components in addition to the phytoplankton (Hansen et al. 1994b). All mesozooplankton biomass and production data are incorporated into the framework of a pelagic carbon budget model covering August 27 to September 17, 1994, along with data originating from the 2 companion papers by Nielsen \& Hansen (1999, in this issue) and by Levinsen et al. (1999, in this issue) to describe the effects on lower trophic levels.

\section{MATERIALS AND METHODS}

Study site. This investigation was conducted from July 17 to September 17,1994, approximately 1 nautical mile off shore from Qeqertarsuaq (Godhavn) $\left(69^{\circ} 15^{\prime} \mathrm{N}, 53^{\circ} 33^{\prime} \mathrm{W}\right)$ at $250 \mathrm{~m}$ depth in Disko Bay (see Nielsen \& Hansen (1999) for further details of sampling scheme, water temperature, phytoplankton biomass, primary production etc.). The euphotic zone was determined to equal $30 \mathrm{~m}$ of the water column.

Potential zooplankton food. Sampling for particulate organic material was conducted at 5 or 6 depths in the upper $30 \mathrm{~m}$ using a $10 \mathrm{l}$ Niskin water bottle (Nielsen \& Hansen 1999). To distinguish roughly between potential copepod food and protozooplankton food, the chlorophyll samples were fractionated into size fractions $>11$ and $<11 \mu \mathrm{m}$, respectively. Major phytoplankton taxa were quantified by inverted microscopy, and phytoplankton biomass was estimated by cell volume and literature carbon content (Edler 1979). Protozooplankton biomass was determined from abundances obtained from counting using inverted microscopy (Levinsen et al. 1999). 
Zooplankton sampling, identification and quantification. Mesozooplankton was sampled by vertical hauls with a WP-2 net (200 $\mu \mathrm{m}$ mesh size) and the smaller taxa were sampled occasionally, but at every visit to the station after August 23, in the upper $50 \mathrm{~m}$ with a Hensen net ( $45 \mu \mathrm{m}$ mesh size). Both nets were equipped with a flow meter (Digital Model 438110 Hydro Bios) and large non-filtering cod-ends. The vertical distribution of mesozooplankton was described by sampling in 2 or 3 depth strata $(0$ to $50 \mathrm{~m}, 50$ to $150 \mathrm{~m}$, and $150 \mathrm{~m}$ to the bottom). To present the abundance of the entire zooplankton community in the upper $50 \mathrm{~m}$, the catch results from the 2 net types were combined as inspired by Vanucci (1968), where numbers refer to body size:

$$
\begin{gathered}
(5000 \text { to } 600 \mu \mathrm{m})_{\text {WP- } 2} \\
+\left(\frac{(600 \text { to } 200 \mu \mathrm{m})_{\text {WP }-2}+(600 \text { to } 200 \mu \mathrm{m})_{\text {Hensen }}}{2}\right) \\
+(200 \text { to } 45 \mu \mathrm{m})_{\text {Hensen }}
\end{gathered}
$$

because the WP-2 net filters zooplankton below $200 \mu \mathrm{m}$ in body size less efficiently and the Hensen net cannot catch zooplankton representatively when they are above $200 \mu \mathrm{m}$ in body size.

The zooplankton samples were immediately preserved in $2 \%$ buffered formalin and at least 300 individuals were counted and cephalothorax length of copepods was measured. The carbon content or the ash-free dry weight of meroplankton and holozooplankton, including all copepod stages and species, were obtained from the literature: Calanus spp. copepodites and Metridia longa from Hirche \& Mumm (1992), Acartia spp. from Berggreen et al. (1988), Oithona spp. from Sabatini \& Kiørboe (1994), Microsetella norvegica calculated as Oithona, Pseudocalanus spp. from Klein Breteler et al. (1982), copepod nauplii from Berggreen et al. (1988), bivalve veligers from Fotel et al. (1999), gastropod veligers from Hansen \& Ockelmann (1991), and echinoderm larvae calculated as bivalve veligers. The carbon content of Calanus spp. copepodite stages I to III and the smaller species of copepods was assumed to be $50 \%$ of the dry weight, while a conversion factor of $60 \%$ was used for the older stages of Calanus spp. (Omori 1969, Hansen et al. 1994a). Copepods (copepodite stages) are presented in 2 main categories: large, which refers to Calanus spp. and $M$. longa; small, which refers to the rest of the copepod taxa. In this differentiation nauplii are not taken into consideration.

Egg production. A sample of gently collected mesozooplankton from the upper $75 \mathrm{~m}$ was diluted in surface water and brought to the laboratory. One to 5 ripe females were incubated with surface sea water in $600 \mathrm{ml}$ acid-cleaned polycarbonate bottles for $24 \mathrm{~h}$. However, due to lack of ripe female Metridia spp. and Calanus spp., the investigation concentrated on Acar- tia longiremis, with at least 4 replicate bottles per measurement. The bottles were kept in the shade and incubated at a temperature not far from in situ temperature in a glacier stream $\left(1.5\right.$ to $\left.2^{\circ} \mathrm{C}\right)$ close to the Arctic Station. Egg production was not corrected for this temperature difference. At the end of the incubation the spawned eggs were counted. Carbon content of $A$. longiremis eggs was estimated from egg volume by assuming $0.14 \mathrm{pg} \mathrm{C} \mathrm{mm}^{-3}$ (Kiørboe et al. 1985). The female cephalothorax lengths were measured. Female copepods were individually washed in $0.2 \mu \mathrm{m}$ filtered sea water and dried at $60^{\circ} \mathrm{C}$ for $24 \mathrm{~h}$ before deep freezing. The carbon content of females was measured with an infrared gas analyzer (IRGA; ADC $225 \mathrm{MK} 3$ ) after combustion in a tube furnace at $650^{\circ} \mathrm{C}$. The carbon signal was calibrated with glucose solute in glass distilled water. The obtained length-carbon relationship was used to convert daily egg production per female into specific egg production. The community production is based on the assumption that the juvenile somatic growth rates were equal to specific egg production rates (Berggreen et al. 1988) and that all copepod species had equal specific production.

We tested which factors were controlling the egg production by Acartia longiremis using path analysis which allows the partitioning of correlations between variables into direct effects of one variable on another and indirect environmental and biological effects (Banta et al. 1995, Sokal \& Rohlf 1995). Path analysis is conducted based on the hypothetical relationships influencing the egg production rate shown schematically in Fig. 1.

Carbon budget. To construct a carbon budget, depth integrated values of the biomass and production of the phytoplankton and the bacteria were taken from Nielsen \& Hansen (1999), protozooplankton data were taken from Levinsen et al. (1999) and the metazooplankton data from the present study. Meroplankton are assumed to have a specific production of $0.05 \mathrm{~d}^{-1}$ (Hansen et al. 1997). All standing stocks (and rates) are presented as $\mathrm{mg} \mathrm{C} \mathrm{m}^{-3}\left(\mathrm{~d}^{-1}\right)$ as mean values of all sampling dates obtained by trapezoidal integration in the upper $30 \mathrm{~m}$. The integrated production was obtained by applying the measured/assumed growth to the biomass of the entire community in the upper $30 \mathrm{~m}$. Zooplankton grazing was calculated assuming a gross growth efficiency of $33 \%$ (Hansen et al, 1997).

\section{RESULTS}

\section{Potential zooplankton food}

During the second part of this study (defined as August 27 to September 17) the integrated mean 


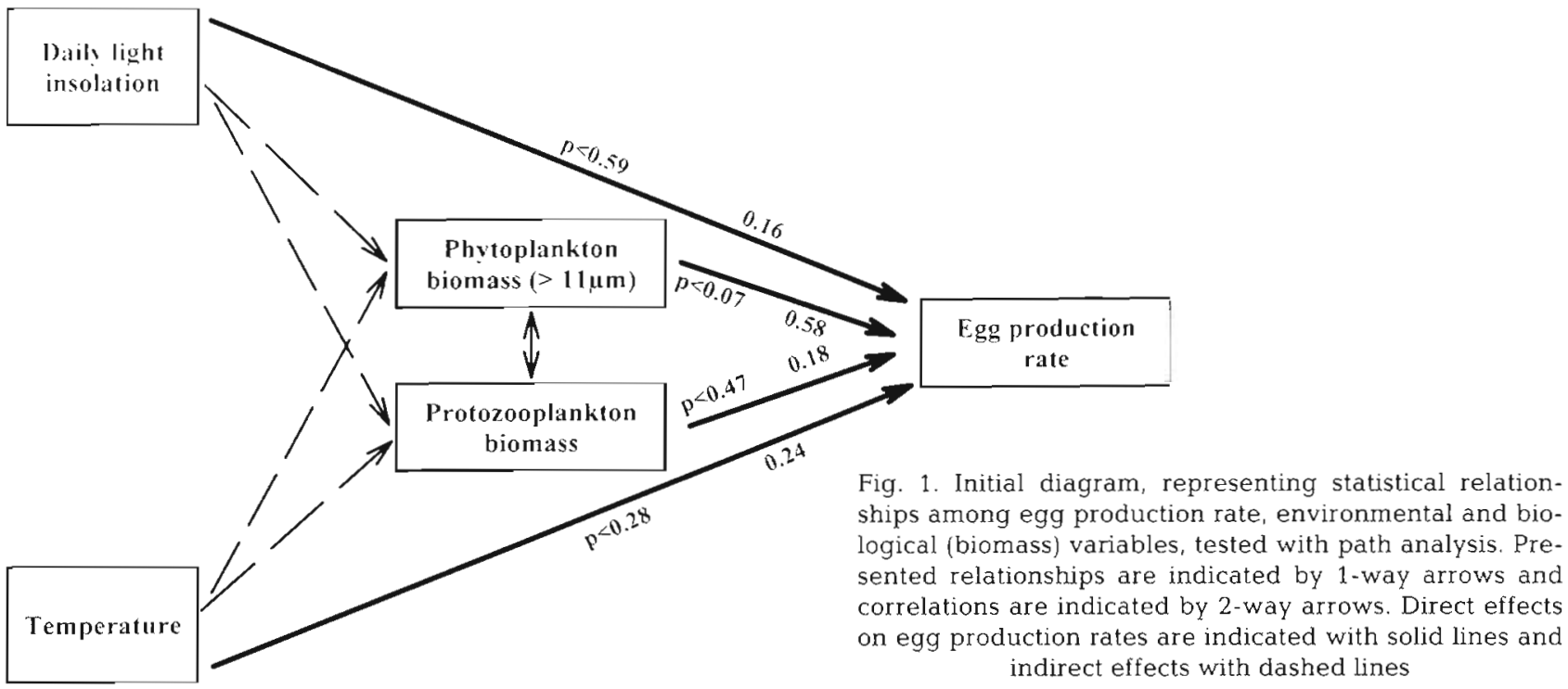

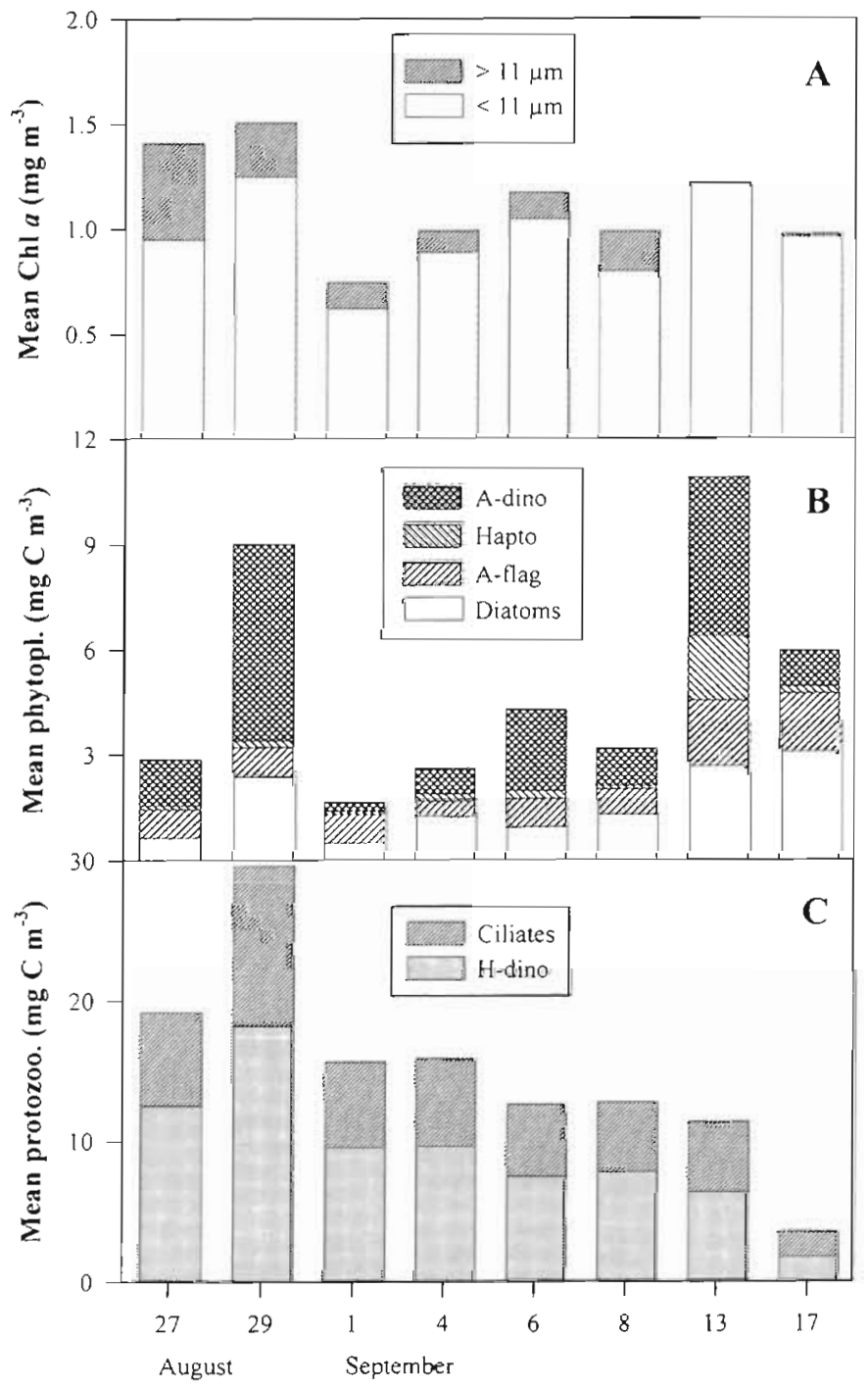

chl $a$ value in the euphotic zone $(0$ to $30 \mathrm{~m})$ was constant around $1 \mathrm{mg} \mathrm{m}^{-3}$ throughout the period (Fig. 2A). The size fractionation into potential copepod $(>11 \mu \mathrm{m})$ versus protozooplankton $(<11 \mu \mathrm{m})$ algal food particles revealed that the amount of copepod food decreased from $33 \%$ of the total phytoplankton biomass to almost zero. This picture is further emphasized when the phytoplankton species composition is taken into account (Fig. 2B). Small autotrophic dinoflagellates dominated initially (August 27 to 29), but thereafter contributions by autotrophic nanoflagellates and diatoms $<11 \mu \mathrm{m}$ in cell size were relatively equal. In mid-September the haptophytes composed $15 \%$ of the phytoplankton biomass. The carbon:chlorophyll ratio was surprisingly low based upon the integrated values in the second part of the study period. Therefore a factor of 43 was implied by a linear regression of microscopic examination versus chl a measurements during the entire study period from July 17 to September 17 (Nielsen \& Hansen 1999).

The biomass of protozooplankton, also potential copepod food, revealed that the heterotrophic dinoflagellates dominated in the beginning and after a few days ciliates were present at roughly the same biomass. Total biomass of protozooplankton declined all through the period (Fig. 2C).

Fig. 2. Potential mean concentration of zooplankton food in the euphotic zone $(30 \mathrm{~m})$ for the second part of the study period (August 27 to September 17); (A) integrated fractionated chl $a_{1}>11 \mu \mathrm{m}$ and $<11 \mu \mathrm{m}_{i}(\mathrm{~B})$ phytoplankton biomass given as major taxa; and (C) protozooplankton biomass as ciliates and heterotrophic dinoflagellates at the Disko Bay station during summer-autumn 1994 

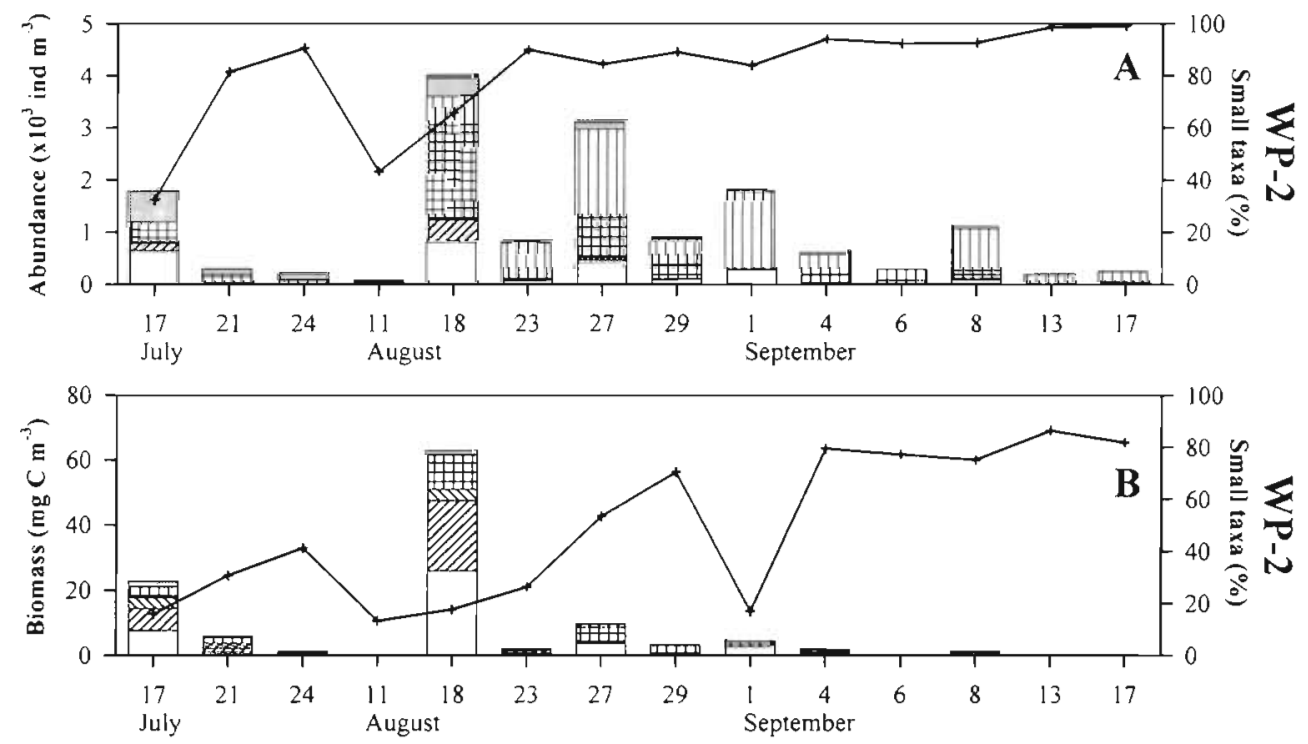

Fig. 3. Abundance and biomass of copepods in the upper $50 \mathrm{~m}$ of the water column. (A, B) Zooplankton collected with a WP-2 net $(200 \mu \mathrm{m}$ mesh size) for the entire study period. (C, D) Zooplankton collected with a Hensen net $(45 \mu \mathrm{m}$ mesh size) for the second part of the study period (August 27 to September 17). The percentage of small copepod taxa (Acartia, Oithona, Pseudocalanus and Microsetella) is indicated by the line

\section{Mesozooplankton abundance and distribution}

Copepods dominated the mesozooplankton in the upper $50 \mathrm{~m}$ of the water column. The abundance fluctuated between a few hundreds to 8000 ind. $\mathrm{m}^{-3}$ (Fig. 3). The copepod community was composed of the large Calanus spp. and Metridia longa and a group of smaller copepods represented by Acartia spp., Pseudocalanus elongatus, Microsetella sp. and Oithona similis. The group of 'others' was composed of Centropages hamatus, Euchaeta sp., Aetiidae, Microcalanus pusillus, Oithona spinirostris, Oncaea spp., which were generally negligible in abundance as well as in biomass. Calanus finmarchicus as well as $P$. elongatus and $O$. similis were abundant throughout the entire period, and the biomass was dominated in the upper water mass by Calanus spp. and the small bodied Pseudocalanus spp.
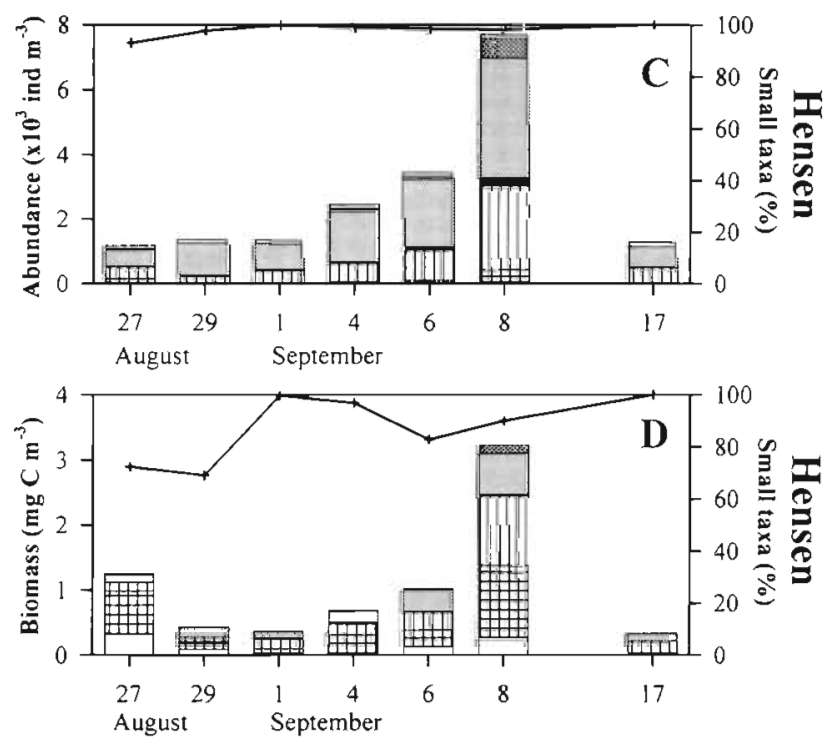

The sampling selectivity of the 2 net types was analysed from the relation of catch efficiencies of some key zooplankters. The large copepods were primarily caught by the WP-2 net (Fig. 3A,B) and the smaller species by the Hensen net (Fig. 3C,D). The relative abundance of the small copepod taxa was increasing during the late summer-autumn from 25 to close to $100 \%$ of the total copepod community. The biomass of copepods caught by the WP-2 net in the upper $50 \mathrm{~m}$ was initially slightly more than $20 \mathrm{mg} \mathrm{C} \mathrm{m}^{-3}$, but thereafter declined, except that a large biomass was observed on August 18 probably due to influx of a new water mass (see Nielsen \& Hansen 1999) (Fig. 3B). In the merged net samples the mutual significance of the small versus the large copepod taxa increased in terms of biomass from 15 to $80 \%$ during the second part of the study period (Fig. 4). 


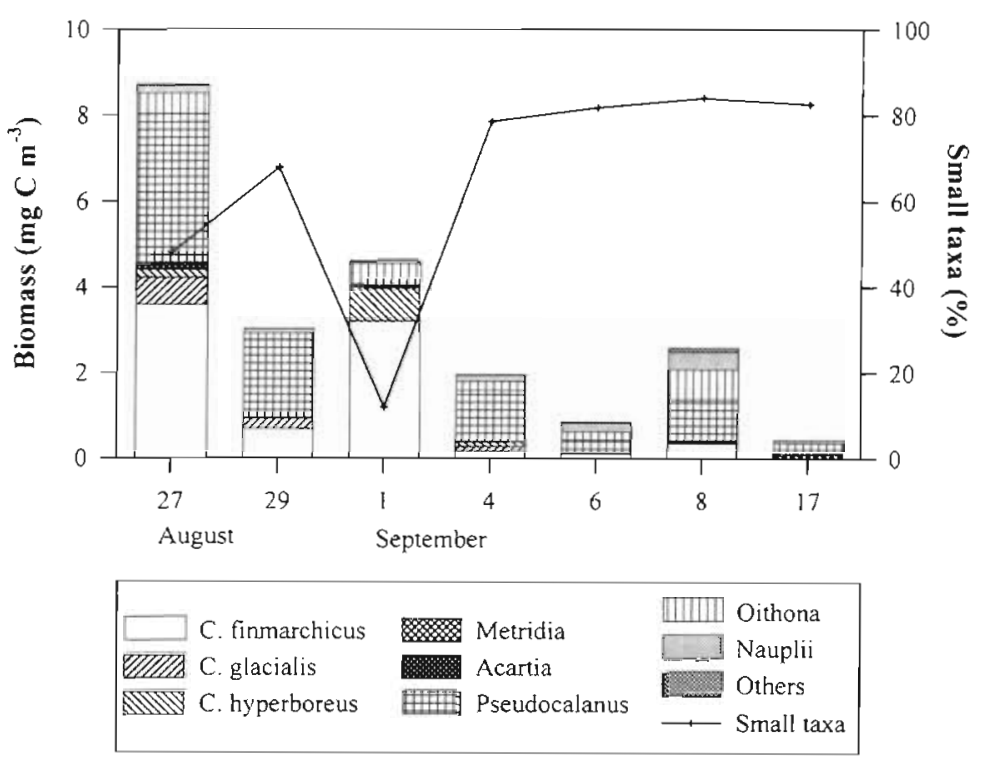

Fig. 4. Biomass of copepods presented as data merged from the WP-2 net and the Hensen net for the second part of the study (August 27 to September 17)

Combining zooplankton biomass data in the second part of the study, when both net types were hauled, reveals that Pseudocalanus elongatus was even more abundant than Calanus finmarchicus most of the time, which was not recognised in the WP-2 data (Fig. 4).
The meroplankton community in the upper $50 \mathrm{~m}$ was dominated by bivalve larvae in August and by gastropod larvae in September. Gastropod veligers increased in abundance and biomass in September (Fig. 5), Besides the common taxa, cirriped nauplii, polychaete larvae and some unidentified larvae were found and are presented here as 'invertebrate larvae', which were low in quantity. The catch efficiency of zooplankton was much higher for the Hensen net than for the WP-2 net for some taxa (Fig. 5A,B vs C,D). The Hensen net was most efficient at catching the small copepods such as Oithona similis and the copepod nauplii (Table 1). In addition, the slow swimming taxa like appendicularians and the thecosomata and the gastropod larvae were caught far more efficiently by the $45 \mu \mathrm{m}$ net (Table 1). The large copepods with a welldeveloped escape response were caught most efficiently by the coarser WP-2 net.

When comparing the total metazooplankton community it is obvious that the abundance of meroplankton was generally low in comparison to holoplankton, except on September 8 when the abundance of meroplankton accounted for close to $40 \%$ of the total metazooplankton abundance in the upper $50 \mathrm{~m}$ (Fig. 6).
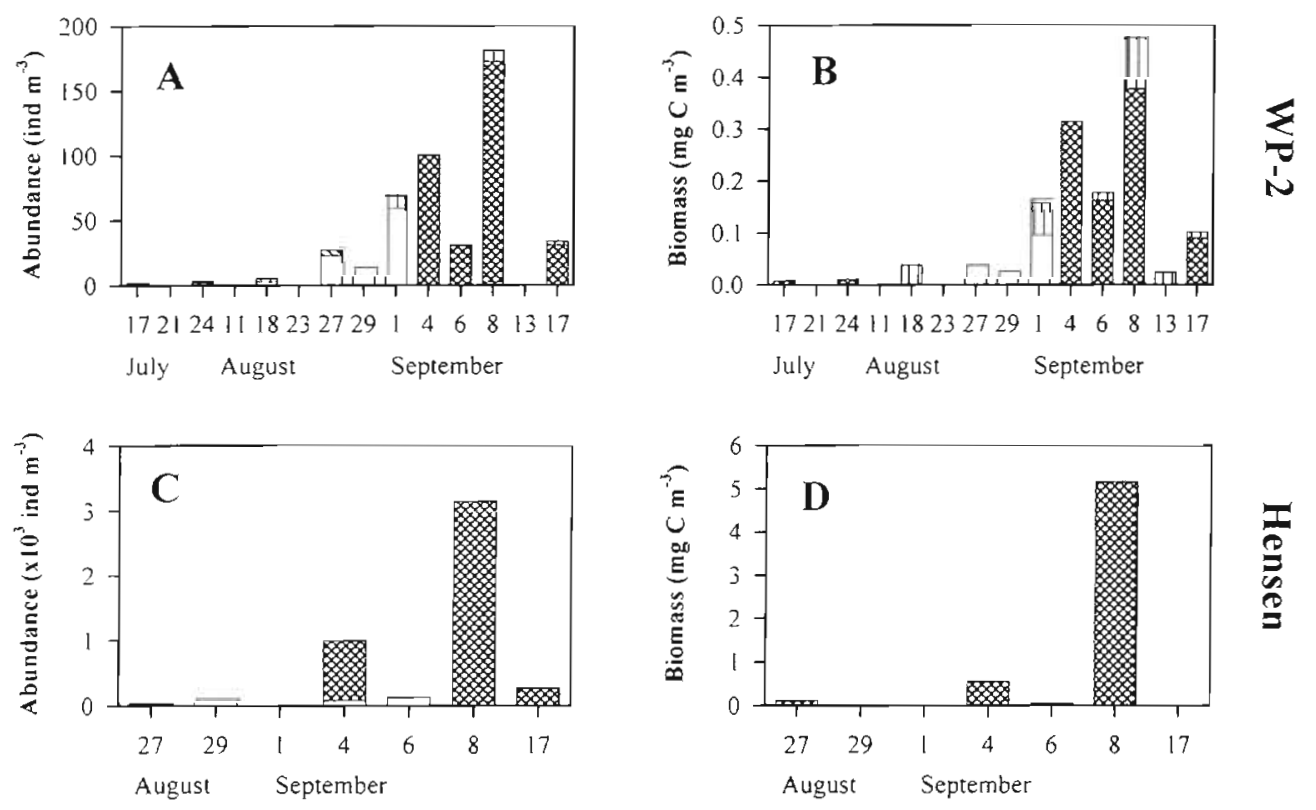

Fig. 5. Abundance and biomass of meroplankton in the upper $50 \mathrm{~m}$ of the water column. (A, B) Zooplankton collected with a WP-2 net (200 um mesh size) for the entire study period. (C. D) Zooplankton collected with a Hensen net (45 $\mu \mathrm{m}$ mesh size) for the second part of the study period (August 27 to September 17) 
Vertical distribution changed during the study. Copepod biomass decreased in the upper $50 \mathrm{~m}$ from $5-8$ to $<1 \mathrm{mg} \mathrm{C} \mathrm{m}{ }^{-3}$ ( 35 to $2 \%$ of the per area standing stock) as the study progressed (Fig. 7). The copepods migrated during summer to intermediate water strata where the biomass was 10 to $22 \mathrm{mg} \mathrm{C}$ $\mathrm{m}^{-3}$ (71 to $16 \%$ of the per area standing stock). The bulk of the copepods were situated in deeper water (5 to $39 \mathrm{mg} \mathrm{C} \mathrm{m}^{-3}$, corresponding to $27-96 \%$ of the per area standing stock), especially in September.

The abundance of the smaller copepod taxa peaked in the upper $50 \mathrm{~m}$ of the water column where the nauplii were also concentrated. Acartia longiremis was observed in the upper $50 \mathrm{~m}$ from late August throughout the study period at a low biomass (Fig. 7, see also Fig. 10A). The deeper water strata were dominated by the large Calanus spp. and Metridia longa.

The developmental stage composition was analyzed for the Calanus spp. populations with a focus on the copepodites sampled with the WP-2 net. Data are presented for the 5 dates covering late August until mid-September when 3 depth strata were sampled (Fig. 8). The abundance was dominated by C. finmarchicus, with up to $>200$ ind. $\mathrm{m}^{-3}$ followed by C. glacialis, and low abundance of C. hyperboreus. C. glacialis was not present in the upper $50 \mathrm{~m}$ and $C$. hyperboreus was found almost only in the deep water. All through the study period and especially at the end of August, the upper $50 \mathrm{~m}$ strata were only populated by juvenile copepodites (stages I, II and III). Few CIs were found in the intermediate water strata and none in the deep water strata. In the intermediate water strata the stage composition appeared more advanced, with primarily CIII, IV and a few CV copepodites. The overwintering CIV stage of C. glacialis (Hirche 1991) was mainly observed below $150 \mathrm{~m}$ in September. The overwintering stages of C. finmarchicus (CIV, CV and adults) (Tande 1991) were present at 50 to $150 \mathrm{~m}$ and below. Generally, in the bottom water the stage composition was skewed toward older stages, with a peak abundance of CIVs and a relatively large fraction of CVs and adult Calanus spp.

\section{Zooplankton production, grazing and the carbon budget}

The relation between body weight and cephalothorax length for females of Acartia longiremis showed a range in cephalothorax size between 725 and $975 \mu \mathrm{m}$ and a body carbon content of approximately 2 to $5 \mu \mathrm{g}$ $C$ female ${ }^{-1}$, leading to a power function with a slope of $b=2.9$ (Fig. 9).

The mean egg production rate by Acartia longiremis declined from 10 to $<2$ eggs female ${ }^{-1} \mathrm{~d}^{-1}$ throughout

Table 1. Relation between catch efficiencies obtained by Hensen $(45 \mu \mathrm{m}) / \mathrm{WP}-2(200 \mu \mathrm{m})$ nets of some key zooplankters. Hensen: animals only caught in Hensen net; WP-2: animals only caught in WP-2 net; 0 : no animals caught in either of the 2 nets

\begin{tabular}{|lccccccccc|}
\hline Date & C. finmarchicus & Acartia & Pseudo & Oithona & Nauplii & Larvacea & Thecosomata & Bivalvia & Gastropoda \\
\hline Aug 27 & 0.09 & 0.01 & 0.17 & 0.16 & 0.49 & 0.23 & 0.12 & 0.73 & 0.00 \\
Aug 29 & 0.13 & 0.20 & 0.06 & 0.27 & 17.52 & 1.21 & 15.83 & 1.56 & 0 \\
Sep 1 & 0.00 & 0.06 & WP-2 & 0.20 & 3.61 & 0.10 & 0.37 & 0.15 & 0 \\
Sep 4 & 0.09 & 0.29 & 0.23 & 0.77 & 3.42 & 0.00 & 0 & Hensen & 0.60 \\
Sep 6 & 1.03 & 0.69 & 0.89 & 2.98 & 66.71 & 47.26 & Hensen & 0 & Hensen \\
Sep 8 & 0.75 & 0.22 & 1.83 & 3.07 & 12.14 & 0.00 & 0 & 0 & 0.07 \\
Sep 17 & 0.00 & 0.11 & 0.30 & 1.71 & 22.05 & 0.00 & 0 & 0.00 & 3425.28 \\
Mean \pm SD & $0.30 \pm 0.42$ & $0.23 \pm 0.23$ & $0.58 \pm 0.68$ & $1.31 \pm 1.29$ & $20.0 \pm 22.9$ & $6.97 \pm 17.77$ & $5.44 \pm 9.00$ & $0.61 \pm 0.71$ & $857 \pm 1713$ \\
\hline
\end{tabular}




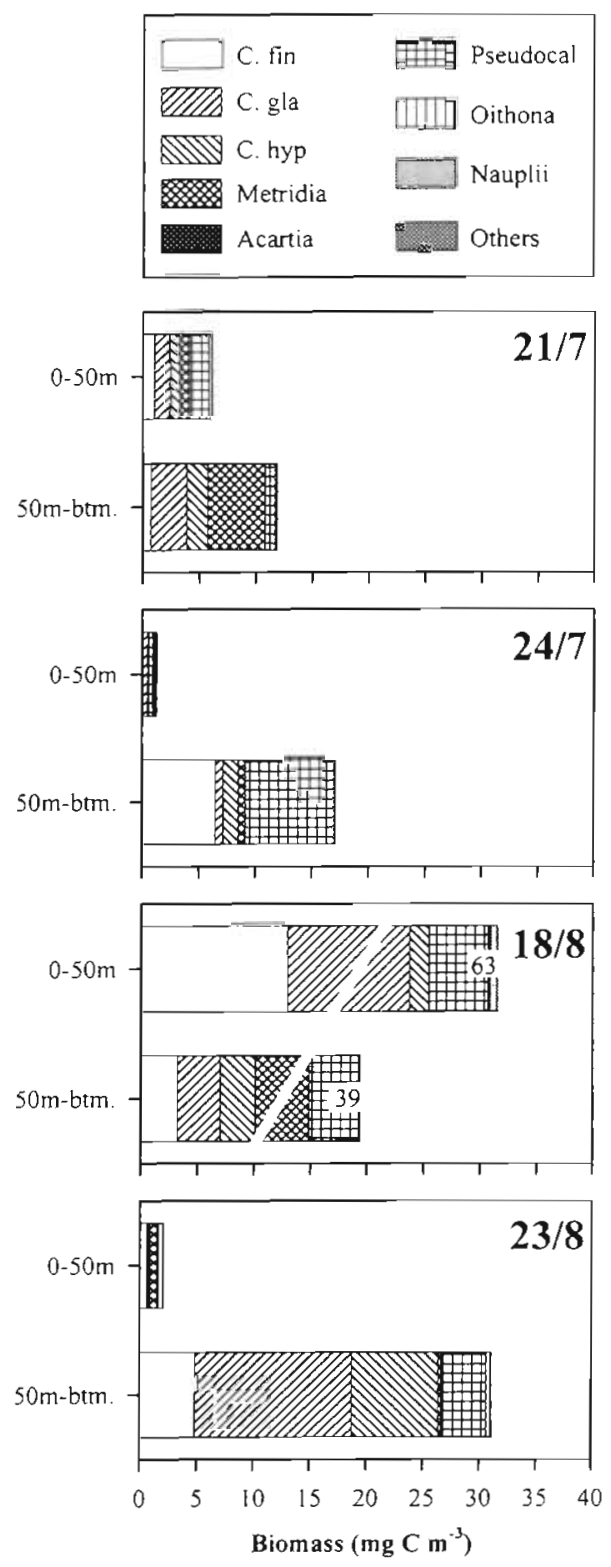

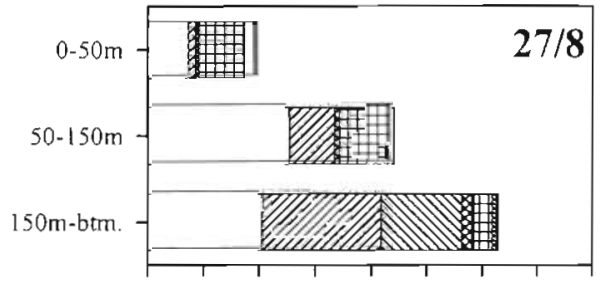
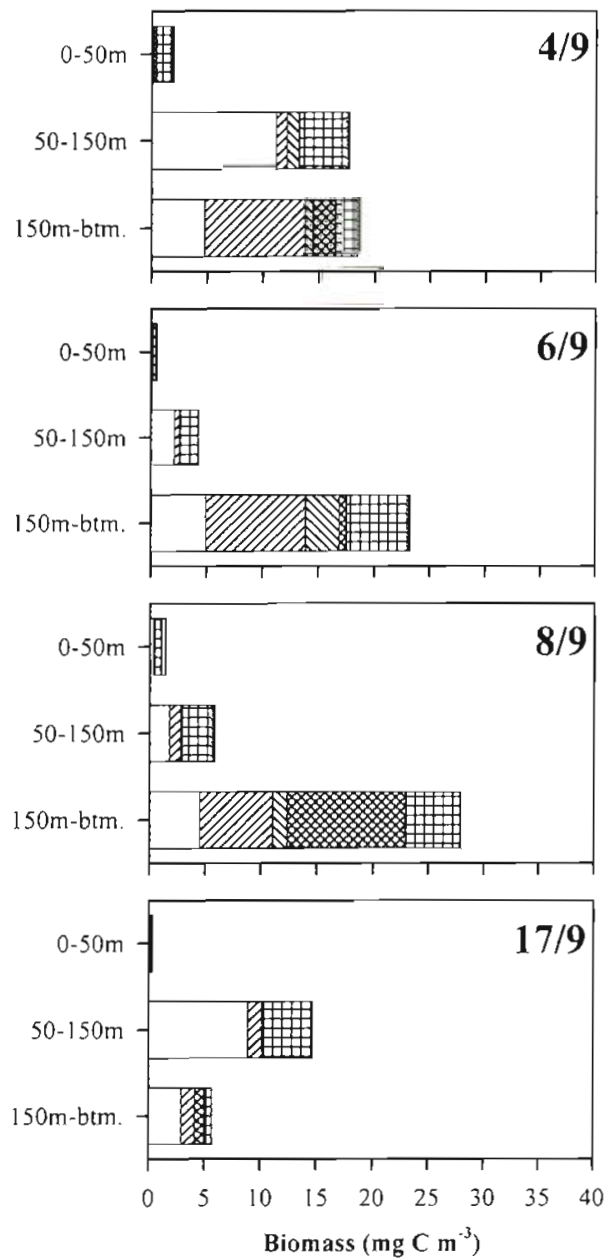

Fig. 7. Vertical distribution of copepod biomass during 2 mo in $2(0-50 \mathrm{~m}$ and $50 \mathrm{~m}$ to bottom) or 3 depth strata $(0-50 \mathrm{~m}$, $50-150 \mathrm{~m}$ and $150 \mathrm{~m}$ to bottom). Note that the scale for August 18 goes to $80 \mathrm{mg} \mathrm{C} \mathrm{m}^{-3}$. Sequence of species in the bars is from left to right late summer (Table 2). This equals a specific egg production rate of 0.11 to $0.02 \mathrm{~d}^{-1}$ (Fig. 10B).

According to the path analysis, egg production was significantly associated primarily with the biomass of phytoplankton $>11 \mu \mathrm{m}$ and secondarily with the proto- zooplankton biomass, which in turn was associated with daily light insolation (see 'Discussion') (Fig. 11).

The biomass contribution of the different taxonomic and functional zooplankton groups during the second part of the study period revealed a well-developed

Table 2. Acartia longiremis. Daily egg production rate (mean $\pm \mathrm{SE}$ and maximum and minimum) with number of experiments in parentheses

\begin{tabular}{|lccccccc|}
\hline Aug 27 & Aug 29 & Sep 1 & Sep 4 & Sep 6 & Sep 8 & Sep 13 & Sep 17 \\
\hline $10.0 \pm 4.2$ & $7.9 \pm 0.9$ & $6.0 \pm 0.8$ & $4.9 \pm 0.7$ & $3.6 \pm 0.3$ & $3.8 \pm 0.6$ & $3.1 \pm 0.7$ & $1.6 \pm 0.4$ \\
$33,4(6)$ & $13,4(10)$ & $8,0.3(9)$ & $9,3(8)$ & $5,2(10)$ & $7,1(11)$ & $6,2(4)$ & $5,0.3(10)$ \\
\hline
\end{tabular}




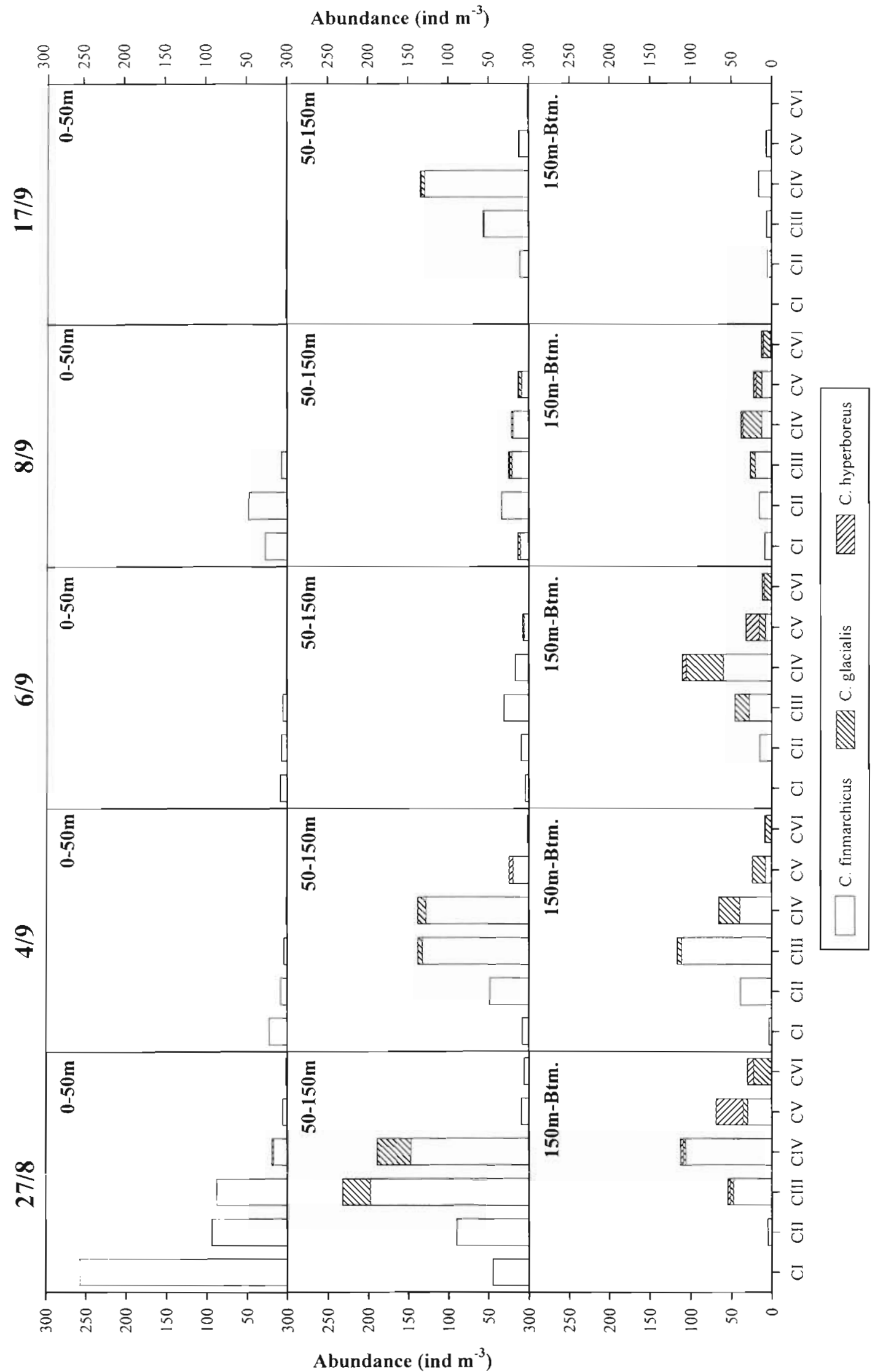




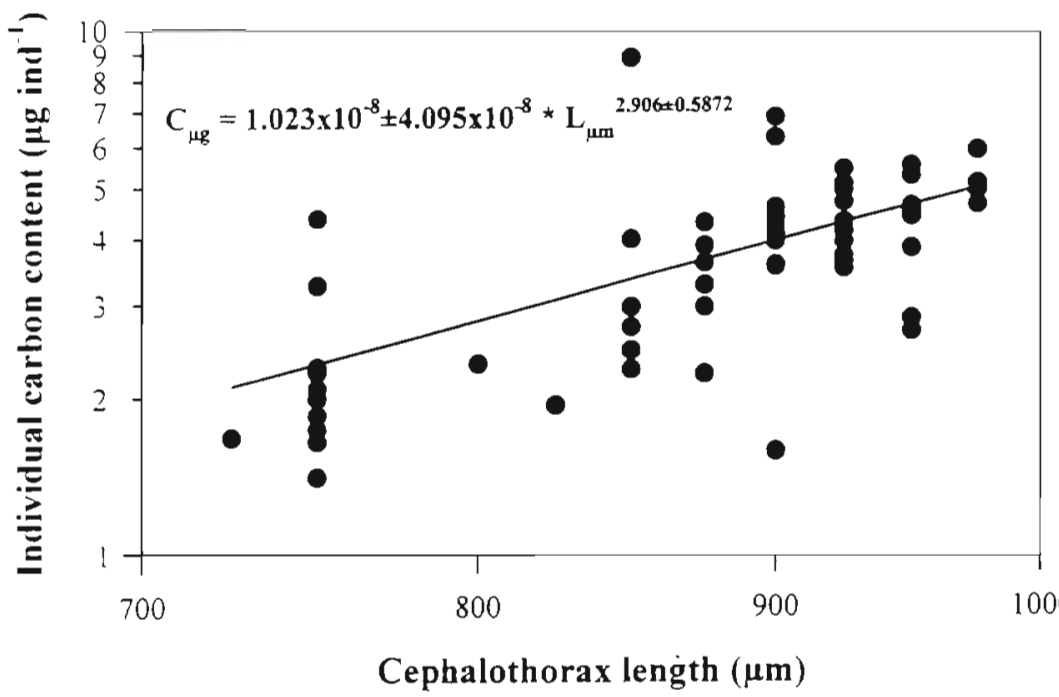

Fig. 9. Acartia longiremis. Relation between body weight and cephalothorax length in females

protozooplankton community (Fig. 12). The meroplankton was only sparsely present in September and especially on September 8, while the copepods generally comprised less than $30 \%$ of the total zooplankton biomass (Fig. 12A).

The community production of zooplankton revealed a dominance of protozooplankton with occasional minor contributions of copepods and meroplankton.

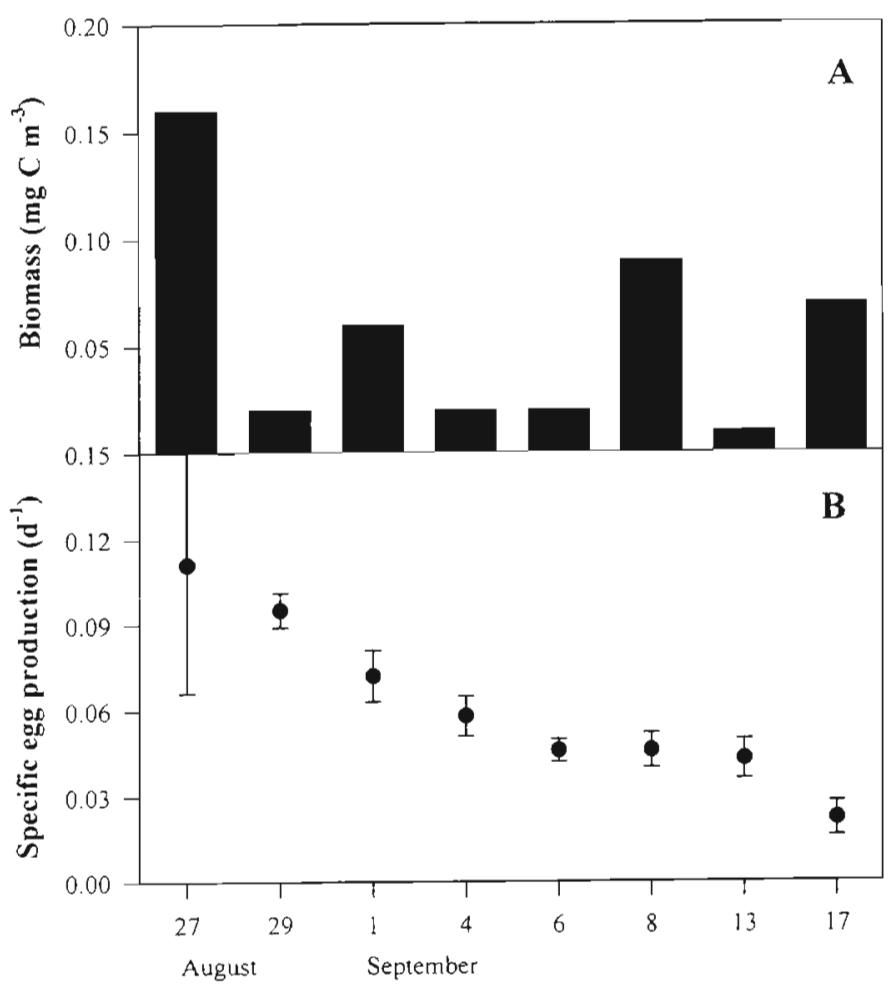

Fig. 10. Acartia longiremis. (A) Biomass, (B) specific egg production rate (mean \pm SE) during late August to mid-September 1994
This picture is of course reflected in the zooplankton community grazing (Fig. 12B).

All the reported data from Nielsen \& Hansen (1999) and Levinsen et al. (1999) as well as from the present study are put into a quantitative perspective by means of depth integrated values of biomass pools and production as well as loss processes in the euphotic zone ( 0 to $30 \mathrm{~m}$ ) covering late summer-autumn, August 27 to September 17, in Disko Bay in order to construct a pelagic carbon budget model (Fig. 13).

\section{DISCUSSION}

\section{Potential zooplankton food}

The phytoplankton community was characterized by 3 subsurface blooms during the 2 mo investigation (Nielsen \& Hansen 1999). However, the phytoplankton biomass was relatively constant and low during the second part of the investigation, i.e. August 27 to September 17. Most of the phytoplankton was $<11 \mu \mathrm{m}$ in cell size. This material is barely retainable and if so only with a reduced efficiency for large copepods and large heterotrophic dinoflagellates. This cell size composition, however, was well within the retention spectra for ciliates, ciliated meroplankton and small copepods (Hansen et al. 1994b). Due to the successional shift in phytoplankton composition (Nielsen \& Hansen 1999) it may have forced a functional restructuring among the grazers.

\section{Mesozooplankton abundance and distribution}

Domination of the mesozooplankton community by the large Calanus spp. has been previously reported 


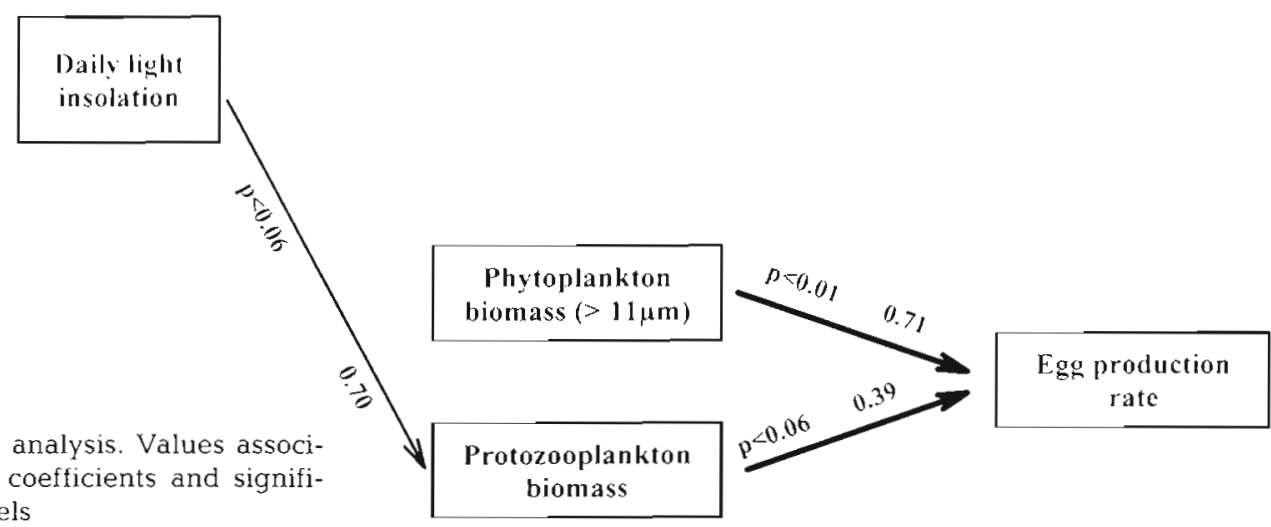

Fig. 11. Final result of the path analysis. Values associated with the arrows are path coefficients and significance levels biomass

nance of C. finmarchicus during August and September, as reported by Smidt (1979) (who used comparabie plankton nets). The increase in the contribution of small copepod species, of up to $80 \%$ in biomass, was obtained during late summer. In Balsfjord, northern Norway, Barthel (1995) reported a continuous increase in the abundance of small zooplankton throughout the year, reaching 60 to $90 \%$ of the total zooplankton biomass in summerautumn, as reported here. The presence of calanoid nauplii in the upper $50 \mathrm{~m}$ in the present study overlapped in time with their presence off Southwest Greenland (Snidt 1979), but nauplii were present more than a month longer in Disko Bay.

In Disko Bay the juvenile Calanus spp. stages dominated the mesozooplankton community in the upper water strata, whereas the more advanced copepodite stages were centered in successively deeper water strata as described from the Barents Sea (Unstad \& Tande 1991, Pedersen et al. 1995) and from a North Norwegian fjord at the same latitude as Disko Bay (Falkenhaug et al. 1997a). In the present study, the possible differences in vertical distribution between day and night were not investigated. At northern latitudes, the changes in diel vertical distribution has been shown to be weak for juvenile stages and modest for more advanced stages of $C$. finmarchicus (Falkenhaug et al. 1997a), and no consistent day-night vertical migration patterns were found in the Barents Sea or Jones Sound for 2 or all 3 Calanus spp. (Head et al. 1985, Hansen et al. 1990).

Meroplankton cannot be collected quantitatively with mesh sizes coarser than $50 \mu \mathrm{m}$. Due to their patchy abundance (e.g. Petersen 1966, Blanner 1982) the relevance for sampling with a Hensen net in addition to
Fig. 12. Biomass of and production and grazing by ciliates, heterotrophic dinoflagellates, meroplankton and copepods in the upper $30 \mathrm{~m}$ of the water column for the second part of the study period. These data are the basis for the grazing estimates in the carbon budget, August 27 to September 17 


\section{Carbon budget \\ $0-30 \mathrm{~m} \mathrm{mg} \mathrm{C} \mathrm{m}{ }^{-3}\left(\mathrm{~d}^{-1}\right)$}

Aug 27 - Sep 171994

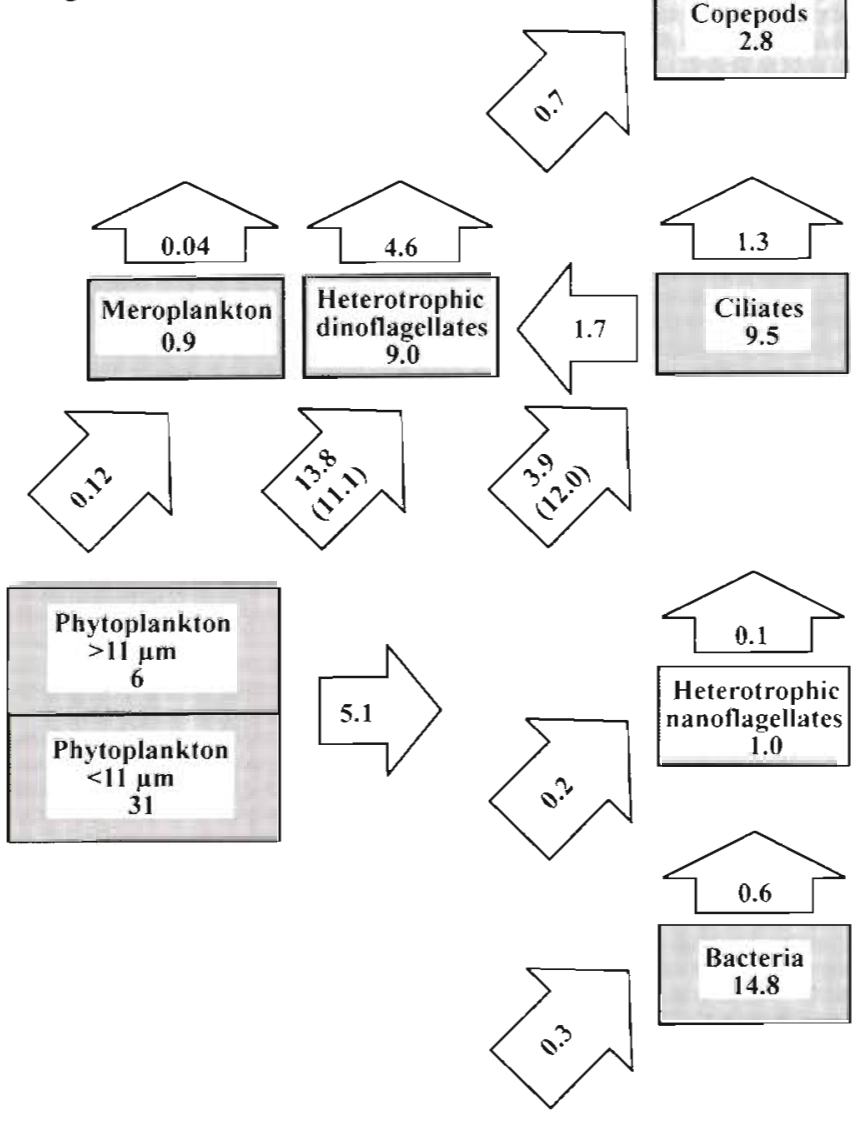

Fig. 13. Carbon flow budget in the euphotic zone (0 to $30 \mathrm{~m})$ based on trapezoidal integrated data from Nielsen \& Hansen (1999), Levinsen et al. (1999) and the present study. Numbers in boxes show average biomass ( $\mathrm{mg} \mathrm{C} \mathrm{m}^{-3}$ ) and numbers on the arrows entering and leaving the boxes represent mean of ingestion and of production, respectively $\left(\mathrm{mg} \mathrm{C} \mathrm{m}^{-3} \mathrm{~d}^{-1}\right)$. Numbers in brackets entering the ciliate biomass represent calculated grazing upon phytoplankton assuming a clearance of $10^{5}$ body volume $\mathrm{h}^{-1}$ (see text) and, for the heterotrophic dinoflagellates, the corrected phytoplankton grazing when grazing upon ciliates is taken into account so the grazing upon phytoplankton is in brackets

the WP-2 net was tested. The abundance of meroplankton was generally low. Despite only Hensen net samples being taken from late August, meroplankton seemed only to be abundant from that period onwards (Fig. 5A,B). The abundance was generally from a few to $200 \mathrm{ind} . \mathrm{m}^{-3}$, but on 2 occasions 1000 and 3000 larvae $\mathrm{m}^{-3}$ were present. At its peak, meroplankton abundance resembled the average for July 1955-1967 in Southwest Greenland (Smidt 1979). The mean abundances in the present study reflect what was recently reported from the North East water polynia off East Greenland, though with a different taxonomic composition, at the same time of year (Clough et al, 1997).

\section{Mesozooplankton life strategies}

In the Arctic Calanus finmarchicus produce 1 generation $\mathrm{yr}^{-1}$, as observed from Northeast Greenland, Southwest Greenland, the Barents Sea and from a subarctic fjord (Ussing 1938, Smidt 1979, Tande 1982 , 1991). C. glacialis presumably performs a 2 way strategy including a 1 and/or a 2 yr life cycle, depending on food availability, as has been proposed for the Barents Sea (Slagstad \& Tande 1990), whereas C. hyperboreus performs a multi-year life cycle, initiating reproduction after more than 2 yr (Conover 1965). Based on the consistent withdrawal from the euphotic zone towards the depths during our study period, we conclude that $C$. finmarchicus and C. glacialis had initiated the winter migration.

All Calanus spp. had finished spawning by late August, which resembles observations from the Barents Sea and the Koster Fjord (Båmstedt \& Tande 1988, Hirche \& Mumm 1992). We did not observe any gut contents in the advanced stages of Calanus spp. (data not shown), which confirms that they reduced activity to minimize respiration loss during hibernation (Hirche 1983, Båmstedt \& Tande 1988). However, after Calanus spp. had left the euphotic zone the small copepods were still present. For the purpose of building a carbon budget model we lump together all small bodied copepod species regardless of their individual food requirements (see Poulet 1978 for particle retention spectra). These small copepods were present in low concentrations, and assuming Acartia longiremis as a representative for the small copepod species they were still producing eggs. The females used for egg production were fertilized, but their individual age of course unknown. Therefore their gonadal cycle status was not checked (Norrbin 1994). But for each experiment mean egg production values were provided based upon 20 to 30 incubated females as representative of the entire female population. This egg production was suggested by the path analysis to be primarily controlled by food availability and not by abiotic factors (Fig. 11). Runge \& Ingram (1991) demonstrated a similar fecundity succession with C. glacialis and Pseudocalanus spp. during summer in Hudson Bay. At the end of our study period the egg production of $A$. longiremis approached zero, suggesting that the end of the reproductive period was reached in mid-September. The reproductive period, based on gonad maturation analysis, is proposed to last from March-April until August-September for Microcalanus spp. and Pseudocalanus spp., which is significantly longer than for the large cope- 
pods in the Barents Sea (Norrbin 1991, 1994). Presumably, after termination of the egg production in September $A$. longiremis initiated overwintering, which is in accordance with a proposed reduction in respiration (Norrbin 1992) and the presence of undeveloped gonads from October to February in Balsfjord, northern Norway (Norrbin 1994). The overwintering stages of the small copepod taxa often include diapause eggs (Marcus 1984) and/or resting stages (Norrbin 1991. 1994). However, it has been documented that $A$. longiremis overwinters as fertilized females with a high lipid content in deep north Norwegian fjords (Davis 1976, Norrbin et al. 1990), which is also reasonable to believe in the case of the population at our $250 \mathrm{~m}$ station in Disko Bay.

We could not determine whether or not our meroplankton larvae were planktotrophic, but presume that some of them were, because the gastropods in particular stayed in the water column for $2 \mathrm{wk}$. In the carbon budget model all meroplankton are assumed to be planktotrophic. If this assumption is correct it is in contradiction to Thorson $(1936,1950)$, who stated that polar benthic invertebrates either have non-pelagic larvae or are lecithotrophic. However, since Thorson's reviews there have been qualitative descriptions of planktotrophic larval species in Greenland (e.g. cirripedia: Petersen 1966; many taxa: Smidt 1979, Andersen 1984, Schmid \& Piepenburg 1993, Clough et al. 1997) which support our suggestion of more diverse life strategies among meroplankton in the Arctic.

\section{Abiotic and biotic factors controlling egg production by Acartia longiremis}

Our expectations of variables influencing the egg production were much more complicated, as illustrated in Fig. 1, than the final results revealed (Fig. 11). But, due to lack of statistical significance the scheme shrank. The path analysis was not developed for including the dynamic trophic interactions between different food web levels because it is a static statistical tool, and it was not very powerful due to limited data. But, the analysis clearly demonstrated that the egg production rate was controlled by the biomass of phytoplankton and secondarily by the biomass of protozooplankton. The surface light energy did not influence the biomass of phytoplankton $<11 \mu \mathrm{m}$. However, it was rather significantly related to the biomass of protozoans. This apparently contrasting result could be explained either as an indirect effect on the protozooplankton prey organisms via the primary production, not shown by the model, or possibly due to the potential mixotrophy by the protozooplankton (Levinsen et al. 1999).

\section{Zooplankton production, grazing and the carbon budget}

Protozooplankton dominated the zooplankton biomass in the euphotic zone generally and therefore also in the second part of the study period, August 27 to September 17. On no occasions did copepods contribute more than $30 \%$ of the total zooplankton biomass, and the meroplankton exceeded $20 \%$ of the total biomass at only 1 sampling (Fig. 12). Due to the higher potential growth rates of the protozooplankton (Levinsen et al. 1999), the secondary production and the calculated grazing were skewed toward protozooplankton dominance. This scenario is parallel to what was found during summer 1992 (Nielsen \& Hansen 1995) and also during spring in the Barents Sea (Hansen et al. 1996).

We hypothesize that the abundance of protozooplankton and the relatively increasing presence of small copepods and meroplankton might be a result of a gradually relaxed food competition and predation from Calanus spp. (Barthel 1988, Runge \& Lafontaine 1996). We propose that when Calanus spp. initiate the winter migration, a niche is created for other organisms, and thereby a restructuring of the grazer food chain. Beside a qualitative change in plankton, one could expect a stimulated biomass development of protozooplankton and small copepods after the large copepods left the photic zone. Concerning small copepods, considered here as a group of species with the same functional biology, although their relative abundance increased dramatically, their biomass remained low. The measured egg production rates were considered reasonable as compared to temperature corrected literature values (Kiørboe et al. 1985) despite a potential risk of underestimation due to egg cannibalism during incubation of several females per bottle without a screen to separate copepods from their eggs (Cabal et al. 1997). This potential egg cannibalism is estimated to be in the range of 10 to $25 \%$ based upon temperature corrected $\left(Q_{10}=2.8\right)$ clearance on particles of the same size as eggs (Tiselius 1989). However, no indications of egg cannibalism could be identified from our raw data wherein 1 to 5 females were incubated in parallel experiments. Another factor that could increase the risk of underestimating egg production could be partial starvation during $24 \mathrm{~h}$ incubation due to clearing the bottles for food particles. This is however not a problem in the present study since Acartia perform low clearance at low temperatures and a rough calculation revealed that at the most one third of the particles would be cleared during 24 h by 5 females. But a slight underestimation of egg production might have happened since all incubations were performed in surface water which contained a chloro- 
phyll concentration only half that of the average of the euphotic zone. In conclusion, the worst case scenario would be an underestimation of egg production by a factor of 3 . The egg production of 1 representative, $A$. longiremis, decreased during the study, and not taking a potential succession in gonadal development towards senescence into account (Norrbin 1994) the egg production was constantly food limited if $A$. longiremis follow the numerical response as reported for $A$. tonsa (Kiørboe et al. 1985; temperature corrected by a $Q_{10}=$ 2.8, Hansen et al. 1997). This corresponds to the results suggested by the path analysis. Additionally, despite little competition with Calanus spp., there was not sufficient time for establishment of another generation or a substantial biomass buildup of small copepods during the autumn in this Arctic ecosystem.

The following carbon budget for August 27 to September 17, 1994 has been constructed basically as budgets reported before in the sparse Arctic literature for a direct comparison. In comparison to 2 summer budgets, before and after a diatom bloom at the same location in June-July 1992 (Nielsen \& Hansen 1995), the phytoplankton composition, biomass and production were fundamentally different during the present study. In 1992 the peak biomass phytoplankton community was dominated by large diatoms mainly fueling protozooplankton and not so much by the high biomass of the Calanus-dominated copepod community. During that study copepod grazing amounted to approximately one third of the protozooplankton grazing upon the phytoplankters, due to differences in energy turnover between the taxa. The copepod grazing in 1992 gave rise to egg production by all 3 Calanus spp. which dominated the mesozooplankton. Despite inspection of very large volumes of water in 1992 we only succeeded in catching Acartia longiremis females on 1 occasion, June 22, when the egg production was 3 eggs female ${ }^{-1}$. The same type of results came from a gradient study in the Barents Sea across the marginal ice zone in May 1993 (Hansen et al. 1996). In the Barents Sea, phytoplankton was dominated by cells $>11 \mu \mathrm{m}$ and most was grazed by protozooplankton ( 100 to $25 \%$ of the daily primary production) and not by the actively reproducing large copepods of the same genera as in Disko Bay in 1992. The comparative biomass composition of the zooplankton revealed that copepods made up only 10 to $20 \%$ of the protozooplankton biomass during the Barents Sea study.

The estimated carbon budget model for the summerautumn period 1994 in Disko Bay (Fig. 13) suggested that a large part of the bacterial production was harvested by the heterotrophic nanoflagellates (Nielsen \& Hansen 1999) which resembled Disko Bay in 1992 and also the Barents Sea in 1993. However, there was not a balance between primary production and the require- ment of phytoplankton carbon for the grazers in the present study if all of the protozooplankton, ciliated meroplankton and the copepods are considered to be entirely herbivorous. In fact the loss due to grazing was a factor of 3 higher than the measured primary production. However, the standing stock of phytoplankton was not observed to crash; it only decreased in biomass throughout the study period. Therefore, some other and less obvious trophic pathways than true herbivory must have been operating, if we exclude the risk of wrong conclusions due to erroneous methodology. The following scenario for the fate of the primary production is proposed: it is a fact that the primary production was dominated by small-celled phytoplankton. The phytoplankton was grazed upon primarily by ciliates and secondarily by ciliated meroplankton in addition to copepods. Even if the community grazing by the copepods was a factor of 3 higher due to underestimation of egg production according to the worst case scenario, the relative significance of copepods as grazers was the same.

The large biomass of and the grazing performed by the heterotrophic dinoflagellates were presumably fuelled not only by the primary producers but also by the ciliates. An assumption of a clearance capacity $(C)$ by heterotrophic dinoflagellates of $10^{5}$ body volume $\mathrm{h}^{-1}$ gives an ingestion $I=C \times$ (ciliate concentration) of $1.7 \pm 0.4 \mathrm{mg} C \mathrm{~m}^{-3} \mathrm{~d}^{-1}$ from the ciliate population (Fig. 13). This trophic interaction is suggested based upon what was observed during the protozooplankton growth incubations performed with $160 \mu \mathrm{m}$ screened water. The growth results all revealed low maximum ciliate growth values as compared to what was observed for heterotrophic dinoflagellates and as accepted literature results show. Hence, internal grazing must have taken place in the incubation bottles and therefore an underestimation in Levinsen et al. (1999). If such grazing occurred, a corrected growth by the ciliates (measured growth plus loss due to grazing from heterotrophic dinoflagellates) gave $4 \mathrm{mg} \mathrm{C} \mathrm{m}^{-3}$ $\mathrm{d}^{-1}$, resembling a specific growth rate of $0.42 \mathrm{~d}^{-1}$, which is more realistic (Nielsen \& Kiørboe 1994, Hansen et al. 1996). To sustain this corrected ciliate growth, however, requires even more of the primary production. Considering an extreme situation where the heterotrophic dinoflagellates grazed solely upon ciliates, the balance in terms of primary production and total loss due to herbivorous grazing was still not established. However, another unknown factor in the present pelagic ecosystem is that we do not know how much of the total autotrophic contribution potentially came from mixotrophic ciliates. Approximately $35 \%$ of the total ciliate biomass was potentially mixotrophic during the carbon budget period (Levinsen et al. 1999). It is likely that a fraction of the carbon shortage due to grazer activity could be found in these 2 trophic inter- 
actions, giving a more complete understanding of the trophic fate of the total primary production. Still no such quantitative evidence is available.

Copepod grazing impact on both ciliates and dinoflagellates is evidenced both in laboratory and in situ (Stoecker \& Sanders 1985, Kleppel et al. 1988, 1991, Gifford \& Dagg 1991). It has been investigated in Scandinavian coastal waters $\left(13\right.$ to $17^{\circ} \mathrm{C}$. Tiselius 1989) as well as in the St. Lawrence Estuary $\left(4.2\right.$ to $8.9^{\circ} \mathrm{C}$, Ohman \& Runge 1994); clearance rate estimates of 16 to $30 \mathrm{ml} \mathrm{g} \mathrm{C}^{-1} \mathrm{~d}^{-1}$ for small copepod species and up to $700 \mathrm{ml}$ per Calanus finmarchicus female $\mathrm{d}^{-1}$ at low chlorophyll conditions have been reported. During the present carbon budget period the phytoplankton biomass was also low and dominated by particles of low retention efficiency for copepods, suggesting alternative feeding strategies. Assuming that a female $C$. finmarchicus contains $160 \mu \mathrm{g}$ of carbon (Nielsen \& Hansen 1995) gives a ciliate clearance of $4.5 \mathrm{ml}$ ( $\mu \mathrm{g}$ copepod C) $)^{-1} \mathrm{~d}^{-1}$ (Ohman \& Runge 1994). Temperature-corrected clearance for small copepods $\left(Q_{10}=2.8\right.$, Hansen et al. 1997) gives approximately $10 \mathrm{ml}(\mu \mathrm{g}$ copepod $\mathrm{C}^{-1} \mathrm{~d}^{-1}$ (Tiselius 1989). An estimated mean grazing impact based upon a clearance of 4.5 to $10 \mathrm{ml}$ $\mu \mathrm{g} \mathrm{C}^{-1} \mathrm{~d}^{-1}$ from copepods on protozooplankton in the euphotic zone is therefore 12 to $28 \mathrm{ml} \mathrm{d}^{-1}$. This equals a mean copepod grazing of 0.4 to $0.9 \mathrm{mg}$ ciliate $\mathrm{C} \mathrm{d} \mathrm{d}^{-1}$ corresponding to $4-9 \%$ of the biomass, or 30 to $67 \%$ of the daily ciliate production in the euphotic zone. Tiselius (1989) reported daily copepod grazing on ciliate biomass to be always $<10 \%$ and generally $<1 \%$ of total copepod grazing, supporting the present calculations. Thus, assuming grazing from heterotrophic dinoflagellates and copepods upon ciliates, they could easily remove the ciliates' daily production during the present study. The copepods also graze upon heterotrophic dinoflagellates (e.g. Kleppel et al. 1988, Gifford \& Dagg 1991). However, this grazing was reported to be a factor of 7.5 lower than upon ciliates, thus insignificant (e.g. Ohman \& Runge 1994). Despite this potential loss, however, the ciliate biomass remained relatively constant while a decrease in heterotrophic dinoflagellate biomass was observed. Since the protozooplankton biomass as well as production, implicit grazing, was rather high all through the study period, it is concluded, as in Nielsen \& Hansen (1995) for a diatom-dominated summer situation, that also during summer-autumn the protozooplankton are more important than the copepods and act as key grazers in the pelagic carbon cycle of Disko Bay.

Acknowledgements. We thank Birgit Søborg, Anne Grete Sørensen and Thomas Wernberg Møller for excellent technical assistance, the crew on RV 'Porsild' for help with sampling and the board of Arctic Station, Copenhagen University, for providing excellent facilities. We are grateful for statistical advice from Gary Banta and we thank Jefferson Turner and Charles Miller and 2 unknown reviewers for critical comments on an earlier draft of the manuscript. The investigation was supported by The Commission for Scientific Research in Greenland (j. No. 5.111/80), Beckett's Foundation (j. no $51001 \mathrm{PV} / \mathrm{LS})$ and The Danish National Research Council proj. no. 9501038 to B.W.H. and T.G.N.

\section{LITERATURE CITED}

Andersen ON (1984) Meroplankton in Jørgen Brønlund Fjord, North Greenland. Medd Grønl Biosci 12

Båmstedt $U$, Tande $K$ (1988) Physiological responses of Calanus finmarchicus and Metridia longa (Copepoda: Calanoida) during the winter-spring transition. Mar Biol 99:31-38

Banta GT, Giblin AE, Hobbie JE, Tucker J (1995) Benthic respiration and nitrogen release in Buzzards Bay, Massachusetts. J Mar Res 53:107-135

Barthel KG (1988) Feeding of three Calanus species on different phytoplankton assemblages in the Greenland Sea. Meeresforsch. 32:92-106

Barthel KG (1995) Zooplankton dynamics in Balsfjorden, northern Norway. In: Skjoldal HR, Hopkins C, Erikstas KE, Leinaas HP (eds) Ecology of fjords and coastal waters. Elsevier Science BV, Amsterdam, p 113-126

Berggreen U, Hansen B, Kiørboe T (1988) Food size spectra, ingestion and growth of the copepod Acartia tonsa during development: implications for determination of copepod production. Mar Biol 99:341-352

Blanner P (1982) Composition and seasonal variation of the zooplankton in the Limfjord (Denmark) during 1973-1974. Ophelia 21:1-40

Cabal J, Harris LR, Head EJH (1997) Egg production rates of Calanus finmarchicus in the Northwest Atlantic (Labrador Sea). Can J Fish Aquat Sci 54:1270-1279

Clough LM, Ambrose WG, Ashjian CJ, Pipenburg D, Ranaud PE, Smith SL (1997) Meroplankton abundance and the Northeast Water Polynia: insights from oceanographic parameters and benthic abundance patterns. J Mar Syst 10:343-357

Conover RJ (1965) Notes on the molting cycle, development of sexual characters and sex ratio in Calanus hyperboreus. Crustaceana 8:308-320

Davis CC (1976) Overwintering strategies of common planktonic copepods in some North Norway fjords and sounds. Astarte 9:37-42

Diel S, Tande K (1992) Does the spawning of Calanus finmarchicus in high latitudes follow a reproducible pattern? Mar Biol 113:21-31

Edler L (1979) Recommendations for marine biological studies in the Baltic Sea. Baltic Mar Biol Publ 5:1-38

Falkenhaug T, Tande KS, Semenova T (1997a) Diel, seasonal and ontogenetic variations in the vertical distributions of four marine copepods. Mar Ecol Prog Ser 149:105-119

Falkenhaug T, Tande K, Timonin A (1997b) Spatio-temporal patterns in the copepod community in Malangen, Northern Norway. J Plankton Res 19:449-468

Fotel FL, Jensen NJ, Wittrup L, Hansen B (1999) In situ and laboratory growth by a population of blue mussel larvae (Mytilus edulis L) from a Danish embayment, Knebel Vig. J Exp Mar Biol Ecol 233:213-230

Gifford DJ, Dagg MJ (1991) The microzooplankton-mesozooplankton link: consumption of planktonic protozoa by the calanoid copepods Acartia tonsa Dana and Neocalanus 
plumchrus Murukawa. Mar Microb Food Webs 5:161-177

Hansen B, Ockelmann KW (1991) Feeding behaviour in larvae of the opistobranch Philine aperta I. Growth and functional response at different developmental stages. Mar Biol 111:255-261

Hansen B, Berggreen UC, Tande KS, Eilertsen HC (1990) Post-bloom grazing by Calanus glacialis, $C$. finmarchicus and $C$. hyperboreus in the region of the Polar Front, Barents Sea. Mar Biol 104:5-14

Hansen B, Verity P, Falkenhaug $T$, Tande KS, Norrbin $F$ (1994a) On the trophic fate of Phaeocystis pouchetii (Harriot). V. Trophic relationships between Phaeocystis and zooplankton: an assessment of methods and size dependence. J Plankton Res 16:487-511

Hansen B, Hansen PJ, Bjornsen PK (1994b) The size ratio between planktonic predators and their prey. Limnol Oceanogr 39:395-403

Hansen B, Christiansen S, Pedersen G (1996) Plankton dynamics in the marginal ice zone of the central Barents Sea during spring: carbon flow and structure of the grazer food chain. Polar Biol 16:115-128

Hansen PJ, Bjørnsen PK, Hansen B (1997) Zooplankton grazing and growth: scaling within the $2-2,000 \mu \mathrm{m}$ body size range. Limnol Oceanogr 42:687-704

Hassel A, Skjoldal HR, Gjøsœter H, Loeng H, Omli L (1991) Impact of grazing from capelin (Mallotus villosus) on zooplankton: a case study in the northern Barents Sea in August 1985. In: Sakshaug E, Øritsland NA (eds) Proceedings of the Pro Mare symposium on polar marine ecology 1990. Polar Res 10:371-389

Hasset PR, Duggins DO, Simenstad CA (1993) Egg production rates of the neritic marine copepod Acartia tumida Willey in the Aleutian Archipelago. Polar Biol 13:515-523

Head E, Harris LR, Abou Debs C (1985) Effect of daylength and food concentration on in situ diurnal feeding rythms in arctic copeods. Mar Ecol Prog Ser 24:281-288

Hirche HJ (1983) Overwintering of Calanus finmarchicus and Calanus helgolandicus. Mar Ecol Prog Ser 11:281-290

Hirche HJ (1991) Distribution of dominant calanoid copepod species in the Greenland sea during late fall. Polar Biol. 11:351-362

Hirche HJ, Bohrer RN (1987) Reproduction of the Arctic copepod Calanus glacialis in Fram Strait. Mar Biol 94:11-17

Hirche HJ, Mumm N (1992) Distribution of dominant copepods in the Nansen Basin, Arctic Ocean, in summer. DeepSea Res 39(Suppl 2):S485-S505

Hirche HJ, Niehoff B (1996) Reproduction of the Arctic copepod Calanus hyperboreus in the Greenland Sea-field and laboratory observations. Polar Biol 16:209-219

Hirche HJ, Kwasniewski S (1997) Distribution, reproduction and development of Calanus species in the Northeast Water in relation to environmental conditions. J Mar Syst 10:299-317

Jespersen (1934) Copepoda. The Godthaab Expedition 1928. Medd Gronl 79:1-166

Kiørboe T, Møhlenberg F, Hamburger K (1985) Bioenergetics of the planktonic copepod Acartia tonsa: relation between feeding, egg production and respiration, and composition of specific dynamic action. Mar Ecol Prog Ser 26:85-97

Klein Breteler WCM, Fransz HG. Gonzales SR (1982) Growth and development of four calanoid copepod species under experimental and natural condition. Neth J Sea Res 16 : 195-207

Kleppel GS, Frazel DW, Pieper RE, Holliday DV (1988) Natural diets of zooplankton off southern California. Mar Ecol Prog Ser 49:231-241.

Kleppel GS, Holliday DV, Pieper RE (1991.) Trophic interac- tions between copepods and microplankton: a question about the role of diatoms. Limnol Oceanogr 36:172-178

Levinsen H, Nielsen TG, Hansen BW (1999) Plankton community structure and carbon cycling on the western coast of Greenland during the stratified summer situation. II. Heterotrophic dinoflagellates and ciliates. Aquat Microb Ecol 16:217-232

Marcus NH (1984) Recruitment of copepod nauplii into the plankton: importance of diapause eggs and benthic processes. Mar Ecol Prog Ser 15:47-54

Marshall SM, Orr AP (1955) The biology of a marine copepod Calanus finmarchicus (Gunnerus). Oliver \& Boyd, Edinburgh

Melle W, Skjoldal HR (1989) Zooplankton reproduction in the Barents Sea: vertical distribution of eggs and nauplii of Calanus finmarchicus in relation to spring phytoplankton development. In: Rydland JS, Tyler PA (eds) Reproduction, genetics and distribution of marine organisms. Proc 23rd Eur Mar Biol Symp. Olsen \& Olsen, Fredensborg. p $137-145$

Miller CB, Cowles TJ, Wiebe PH, Copley NJ, Grigg H (1991) Phenology in Calanus finmarchicus, hypothesis about control mechanisms. Mar Ecol Prog Ser 72:79-91

Nielsen TG, Hansen B (1995) Plankton community structure and carbon cycling on the western coast of Greenland during and after the sedimntation of a diatom bloom. Mar Ecol Prog Ser 125:239-257

Nielsen TG, Hansen BW (1999) Plankton community structure and carbon cycling on the western coast of Greenland during the stratified summer situation. I. Hydrography, phytoplankton and bacterioplankton. Aquat Microb Ecol 16:205-216

Nielsen TG, Kiørboe T (1994) Regulation of zooplankton biomass and production in a temperate, coastal ecosystem, 2 . Ciliates. Limnol Oceanogr 39:508-519

Norrbin MF (1991) Gonad maturation as an indication of seasonal cycles for several species of small copepods in the Barents Sea. In: Sakshaug E, Øritsland NA (eds) Proceedings of the Pro Mare symposium on polar marine ecology 1990. Polar Res 10:421-432

Norrbin MF (1992) Overwintering and energetic strategies of marine pelagic copepods in high latitudes. $\mathrm{PhD}$ thesis, University of Gothenburg

Norrbin MF (1994) Seasonal patterns in gonad maturation, sex ratio and size in some small, high-latitude copepods implications for overwintering tactics. J Plankton Res 16 : $115-131$

Norrbin MF, Olsen RE, Tande KS (1990) Seasonal variation in lipid class and fatty acid composition of two small copepods in Balsfjorden, northern Norway. Mar Biol 105:205-211.

Ohman MD, Runge JA (1994) Sustained fecundity when phytoplankton resources are in short supply: omnivory by Calanus finmarchicus in the Gulf of St. Lawrence. Limnol Oceanogr 39:21-36

Omori M (1969) Weight and chemical composition of some important oceanic zooplankton in the North Pacific Ocean. Mar Biol 3:4-10

Pedersen G, Tande KS, Nilssen EM (1995) Temporal and regional variation in the copepod community in the central Barents Sea during spring and early summer 1988 and 1989. J Plankton Res 17:263-282

Petersen GH (1966) Balanus balanoides (L.) (Cirripedia), life cycle and growth in Greenland. Medd Gronl 159:1-114

Peterson WT, Tiselius P, Kirrboe T (1991) Copepod egg production, moulting and growth rates, and secondary production, in the Skagerrak in August 1988. J Plankton Res 13:131-154 
Plourde S, Runge JA (1994) Reproduction of the planktonic copepod, Calanus finmarchicus, in the lower St. Lawrence estuary: relation to the cycle of phytoplankton production and evidence for a Calanus pump. Mar Ecol Prog Ser 102: $217-227$

Poulet SA (1978) Comparison between five coexisting species of marine copepods feeding on naturally occurring particular matter. Limnol Oceanogr 23:1126-1143

Runge JA, Ingram RG (1988) Underice grazing by planktonic, calanoid copepods in relation to a bloom of ice microalgae in southeastern Hudson Bay. Limnol Oceanogr 33: $280-286$

Runge JA, Ingram RG (1991) Under-ice feeding and diel migration by the planktonic copepods Calanus glacialis and Pseudocalanus minutus in relation to the ice algal production cycle in southeastern Hudson Bay, Canada. Mar Biol 108:217-225

Runge JA, Lafontaine YD (1996) Characterization of the pelagic ecosystem in surface waters of the northern Gulf of St. Lawrence in early summer: the larval redfishCalanus-microplankton interaction. Fish Oceanogr 5: 21-37

Sabatini M, Kiørboe T (1994) Egg production, growth and development of the cyclopoid copepod Oithona similis. J Plankton Res 16:1329-1351

Schmid MK, Piepenburg D (1993) The benthos zonation of the Disko Fjord, West Greenland. Medd Gronl Biosci 37:1-21

Slagstad D, Tande KS (1990) Growth and production dynamics of Calanus glacialis in an arctic pelagic food web. Mar Ecol Prog Ser 63:189-199

Smidt ELB (1979) Annual cycles of primary production and of zooplankton at Southwest Greenland. Medd Grønl Biosci $1: 1-52$

Smith SL (1990) Egg production and feeding by copepods prior to the spring bloom of phytoplankton in Fram Strait,

Editorial responsibility: John Dolan,

Villefranche-sur-Mer, France
Greenland Sea. Mar Biol 106:59-69

Sokal RR, Rohlf FJ (1995) Biometry, 3rd edn. WH Freeman \& Co, New York

Stoecker DK, Sanders NK (1985) Differential grazing by Acartia tonsa on a dinoflagellate and a tintinnid. J Plankton Res. 7:85-100

Tande KS (1982) Ecological investigations on the zooplankton community of Balsfjorden, northern Norway: generation cycles and variations in body weight and body content of carbon and nitrogen related to overwintering and reproduction in the copepod Calanus finmarchicus (Gunnerus). J Exp Mar Biol Ecol 62:129-142

Tande KS (1991) Calanus in North Norwegian fjords and in the Barents Sea. In: Sakshaug E, Øritsland NA (eds) Proceedings of the Pro Mare symposium on polar marine ecology 1990. Polar Res 10:389-407

Thorson G (1936) The larval development, growth and metabolism of Arctic marine bottom invertebrates compared with those of other seas. Medd Gronl 100:1-155

Thorson G (1950) Reproductive and larval ecology of marine bottom invertebrates. Biol Rev 25:1-45

Tiselius P (1989) Contribution of aloricate ciliates to the diet of Acartia clausi and Centrophages hamatus in coastal waters. Mar Ecol Prog Ser 56:49-56

Unstad KH, Tande KS (1991) Depth distribution of Calanus finmarchicus and C. glacialis in relation to environmental conditions in the Barents Sea. In: Sakshaug E, Oritsland NA (eds) Proceedings of the Pro Mare symposium on polar marine ecology 1990. Polar Res 10:409-420

Ussing $\mathrm{HH}$ (1938) The biology of some important plankton animals in the fjords of East Greenland. Medd Gronl 100: $1-108$

Vanucci $M$ (1968) Loss of organisms through the meshes. In: Tranter DJ (eds) Zooplankton sampling. The UNESCO Press, Paris, p $77-86$

Submitted: October 30, 1997; Accepted: July 17, 1998

Proofs received from author(s): February 22, 1999 